\title{
Expression of Progesterone and Androgen Receptors in the Breast of Premenopausal Women, Considering Menstrual Phase
}

\author{
MIA FAHLÉN ${ }^{1,2}$, HUA ZHANG $^{3 *}$, LARS LÖFGREN ${ }^{1}$, BRITT MASIRONI $^{3}$, \\ EVA VON SCHOULTZ ${ }^{2}$, BO VON SCHOULTZ ${ }^{4}$ and LENA SAHLIN ${ }^{3}$ \\ ${ }^{1}$ Capio St. Göran's Hospital, ${ }^{2}$ Department of Oncology and Pathology, \\ ${ }^{3}$ Pediatric Endocrinology Unit, Nordfertil Research Lab, and \\ ${ }^{4}$ Division of Obstetrics and Gynecology, Department of Women's and Children's Health, \\ Karolinska Institute and University Hospital, Stockholm, Sweden
}

\begin{abstract}
Background: Progesterone and androgens are important for normal development and tumorigenesis of the breast. Patients and Methods: Breast tissue samples from 49 premenopausal women were obtained. The progesterone receptors (PRA, PRB, PGRMC1 and PGRMC2) and the androgen receptor $(A R)$ were determined in malignant and benign breast tumors and control tissues. Results: The PRB and AR mRNA levels were highest in tumors. PGRMC1 and PGRMC2 mRNA levels were higher in malignant tumors compared to their paired normal tissues. PRA protein showed most immunostaining in benign tumors. PRB immunostaining varied according to menstrual phase. AR immunostaining was highest in the glands of malignant tumors. Conclusion: Progesterone and androgen receptors are differently regulated in tumors compared to normal breast tissues. A malignant breast tumor could appear PR-negative if collected in the luteal phase, but positive in the follicular phase. This finding may have clinical implications.
\end{abstract}

Steroid hormones and their receptors play a significant part in breast development and in the growth of breast cancer (1). In clinical practice, the estrogen receptor (ER) and the progesterone receptor (PR) are analyzed for predictive and also prognostic purposes (2). The expression of PR indicates a more favorable outcome (3). The most common targets in treatments for breast cancer are either the ER (tamoxifen) or

*Current address: Department of Obstetrics and Gynecology, The First Affiliated Hospital of Chongqing Medical University, Chongqing, P.R. China.

Correspondence to: Mia Fahlén, Capio St Göran's Hospital, St Göransgatan 1, 11381 Stockholm, Sweden. Tel: +46 858701000 , Fax: +46 858701956, e-mail: mia.fahlen@capiostgoran.se

Key Words: Progesterone receptor, androgen receptor, breast cancer, menstrual phase. the conversion of androgen to estrogen by blocking the enzyme aromatase with aromatase inhibitors (4). About 70 to $80 \%$ of all breast cancers express ER and women with ERpositive tumors receive some kind of endocrine treatment. The PR was first discovered in 1970 (5), and exists in three isoforms transcribed from the same gene, PRA, PRB and a non-functional PRC. PR is estrogen dependent and acts in balance with progesterone and ERs in developing the mammary glands (6). PRB is responsible for the development of the mammary gland and PRA is necessary for normal development of the uterus $(7,8)$. A correct balance between PRA and PRB is of importance since PRA exerts an inhibitory effect on PRB. PRA also represses ER and AR (9). An imbalance between PRA and PRB has been observed in breast cancer cells, and may have an impact on tumor development and treatment options for the disease (10). Progesterone acting via $\mathrm{PR}$ mediates maturation of the mammary gland after puberty. It is implied to act through mammary stem cells and by inducing mitogenic factors (11). This raises questions regarding the role of progesterone in breast cancer. Several epidemiological studies show an increased incidence of breast cancer in women using hormone replacement therapy (HRT) (12). In premenopausal women, a correlation between a higher risk of breast cancer and the use of hormonal contraceptives has been noted, although in epidemiological studies performed more recently, the results were ambiguous (13). In a study using natural progesterone in HRT, no increased risk for breast cancer was demonstrated (14).

The progesterone receptor membrane component-1 (PGRMC1) has been analyzed in association with breast cancer and found to be linked to negative clinical outcome and resistance to chemotherapy (15). In addition, PGRMC1 seems to be important in progesterone signaling in triplenegative breast cancer. PGRMC1 was suggested to explain the increased breast cancer risk observed during treatment with certain progestins. A negative correlation between PGMRC1 and age in women has also been demonstrated, 
Table I. Oligonucleotide primers used for real-time polymerase chain reaction.

\begin{tabular}{|c|c|c|c|c|c|c|}
\hline Gene & $\begin{array}{l}\text { Encoded } \\
\text { protein }\end{array}$ & $\begin{array}{c}\text { Accession } \\
\text { no. }\end{array}$ & $\begin{array}{l}\text { Forward }(\mathrm{F}) \text { and } \\
\text { reverse }(\mathrm{R}) \text { primers }\end{array}$ & Position & cDNA & $\begin{array}{l}\text { Annealing } \\
\text { step }\end{array}$ \\
\hline $\begin{array}{l}P G R^{\#} \\
P R-A B^{*}\end{array}$ & $\begin{array}{l}\text { Progesterone } \\
\text { receptor A and B }\end{array}$ & NM_000926.4 & $\begin{array}{l}\text { F: TGGAAGAAATGACTGCATCG } \\
\text { R: AGCATCCAGTGCTCTCACAA }\end{array}$ & $\begin{array}{l}\text { bp } 2555-2574 \\
\text { bp } 2702-2683 \\
\text { product: } 148 \mathrm{bp}\end{array}$ & $50 \mathrm{ng}$ & $56^{\circ} \mathrm{C} / 45 \mathrm{~s}$ \\
\hline $\begin{array}{l}P G R^{\#} \\
P R-B^{*}\end{array}$ & $\begin{array}{l}\text { Progesterone } \\
\text { receptor B }\end{array}$ & NM_000926.4 & $\begin{array}{l}\text { F: GACTGAGCTGAAGGCAAAGG } \\
\text { R: CGAAACTTCAGGCAAGGTGTC }\end{array}$ & $\begin{array}{l}\text { bp } 746-765 \\
\text { bp } 890-870 \\
\text { product: } 145 \mathrm{bp}\end{array}$ & $100 \mathrm{ng}$ & $61^{\circ} \mathrm{C} / 45 \mathrm{~s}$ \\
\hline$A R$ & Androgen receptor & NM_000044.2 & $\begin{array}{l}\text { F: TACCAGCTCACCAAGCTCCT } \\
\text { R: GCTTCACTGGGTGTGGAAAT }\end{array}$ & $\begin{array}{l}\text { bp } 3687-3706 \\
\text { bp } 3881-3862 \\
\text { product: } 195 \mathrm{bp}\end{array}$ & $50 \mathrm{ng}$ & $61^{\circ} \mathrm{C} / 45 \mathrm{~s}$ \\
\hline PGRMC1 & $\begin{array}{l}\text { Progesterone } \\
\text { receptor membrane } \\
\text { component-1 }\end{array}$ & NM_006667.3 & $\begin{array}{l}\text { F: CAAAGGCCGCAAATTCTACG } \\
\text { R: GAGGTCAGAAAGGTCATCGTAC }\end{array}$ & $\begin{array}{l}\text { bp } 419-438 \\
\text { bp } 551-530 \\
\text { product: } 133 \mathrm{bp}\end{array}$ & $50 \mathrm{ng}$ & $56^{\circ} \mathrm{C} / 45 \mathrm{~s}$ \\
\hline PGRMC2 & $\begin{array}{l}\text { Progesterone } \\
\text { receptor membrane } \\
\text { component- } 2\end{array}$ & NM_006320.4 & $\begin{array}{l}\text { F: GCATCCTGCTCGCGGTCAAT } \\
\text { R: TGGAGGCATCCCTACCAGCAA }\end{array}$ & $\begin{array}{l}\text { bp } 1392-1411 \\
\text { bp } 1496-1476 \\
\text { product: } 105 \mathrm{bp}\end{array}$ & $50 \mathrm{ng}$ & $56^{\circ} \mathrm{C} / 45 \mathrm{~s}$ \\
\hline$R P L P O$ & $\begin{array}{c}\text { Ribosomal } \\
\text { phosphoprotein P0 }\end{array}$ & NM_001002.3 & $\begin{array}{l}\text { F: GGCGACCTGGAAGTCCAACT } \\
\text { R: CCATCAGCACCACAGCCTTC }\end{array}$ & $\begin{array}{c}\text { bp } 195-214 \\
\text { bp } 343-324 \\
\text { product:149 bp }\end{array}$ & $50 \mathrm{ng}$ & $62^{\circ} \mathrm{C} / 45 \mathrm{~s}$ \\
\hline
\end{tabular}

*Primers in the same exon. \# (27).

suggesting its role as a predictive factor (15). In addition, it has been suggested that PGMRC1 might be a factor by which progestin in HRT increases the risk of breast cancer (16).

The progesterone receptor membrane component-2 (PGMRC2) is, like PGMRC1, associated with the outcome of breast cancer. Loss of PGMRC2 is linked to stage III cancer but not to stage II. This factor might also be related to metastatic potential $(15,17)$.

The role of the androgen receptor (AR), which was first cloned in 1988 (18), and its effects have been studied in different organs and diseases $(19,20)$. It has long been known to exert an influence in breast cancer and has been a target for treatment since the 1950s (21). The first attempts were with testosterone, followed a couple of years later with fluoxymesterone. These androgenic treatments were discontinued because of their severe side-effects (22). AR expression is most common in ER-positive cancer (60\%), but may also be present in women with triple-negative cancer (26\%). AR expression is associated with higher overall and disease-free survival, and this effect seems to be irrespective of the expression of ER $(23,24)$.

We collected breast tissues from 49 premenopausal women with benign or malignant tumors and the seemingly normal tissue adjacent to the tumor. Results on estrogen and stromal factors have already been published $(25,26)$. In the present study, we aimed to determine the levels of PRA, PRB, PGRMC1, PGRMC2 and AR in the breast tumors and relate them to serum hormone levels, menstrual phase and the Nottingham Prognostic Index (NPI).

\section{Patients and Methods}

Patient characteristics. Thirteen pre-menopausal women with primary invasive ductal breast cancer and 36 women with benign breast disease were invited to participate in a study at Capio St. Görans hospital in Stockholm, Sweden, in order to determine differences in the expression of progesterone and androgen receptors. Samples were collected from benign and malignant tumors, and when possible from the adjacent seemingly normal tissue, to enable paired analyses of the results. Blood samples were also obtained at the time of surgery, to determine hormone levels and the phase of the menstrual cycle. In the group with benign breast disease, 25 women were in the follicular phase, whereas 11 were in the luteal phase. Seven of the women with malignant tumors were in the follicular phase and four in the luteal phase. Please see our previous report for a detailed description of the participants and the serum levels of estradiol, progesterone, free testosterone, steroid hormone binding globulin (SHBG) and insulinlike growth factor-I (IGFI) (25).

The local Ethics Committee of the Karolinska Institute approved the study (no. 98-173) and all women gave their written consent to participation.

Breast tissue sampling. When collected, the samples were frozen $\left(-70^{\circ} \mathrm{C}\right)$ until the analyses were carried out. The samples were either fixed in $4 \%$ phosphate-buffered paraformaldehyde or extracted for RNA and subsequent polymerase chain reaction (PCR) analyses. The fixed samples were embedded in paraffin, cut in 5- $\mu \mathrm{m}$ slices and mounted on glass slides for immunohistochemical analysis. An independent expert pathologist re-evaluated all slides to confirm the diagnosis.

RNA preparation and reverse transcription. The frozen breast tissue samples were first transferred to RNAlater-ICE ${ }^{\circledR}$ (Ambion Inc, Austin, TX, USA). Total RNA was purified with the RNeasy ${ }^{\circledR}$ Lipid 
Table II. The antibodies, concentrations, incubations and buffers used in this study.

\begin{tabular}{|c|c|c|c|c|c|c|c|c|}
\hline Protein & Blocking & $\begin{array}{l}\text { Primary } \\
\text { antibody } \\
\text { source }\end{array}$ & $\begin{array}{c}\text { Primary } \\
\text { antibody } \\
\text { type }\end{array}$ & $\begin{array}{l}\text { Dilution, } \\
\text { incubation }\end{array}$ & $\begin{array}{c}\text { Secondary } \\
\text { biotinylated } \\
\text { antibody }\end{array}$ & $\begin{array}{l}\text { Secondary } \\
\text { antibody }\end{array}$ & $\begin{array}{l}\text { Buffer for } \\
\text { dilution }\end{array}$ & $\begin{array}{l}\text { Negative } \\
\text { control }\end{array}$ \\
\hline PRA & $\begin{array}{l}1.5 \% \mathrm{NHS} \\
30 \mathrm{~min}\end{array}$ & $\begin{array}{c}\text { Novo Castra } \\
\text { NCL-PgR-312 }\end{array}$ & $\begin{array}{c}\text { Monoclonal } \\
\text { mouse IgG }\end{array}$ & $\begin{array}{c}1: 500 \\
\text { RT } 60 \mathrm{~min}\end{array}$ & $\begin{array}{l}\text { Horse anti- } \\
\text { mouse } \operatorname{IgG}^{1}\end{array}$ & $\begin{array}{c}\text { RT } 45 \text { min } \\
1: 200\end{array}$ & $\begin{array}{l}1.5 \% \text { NHS } \\
\text { in PBS }\end{array}$ & $\begin{array}{l}\text { Mouse } \\
\text { IgG }\end{array}$ \\
\hline PRB & $\begin{array}{l}1.5 \% \mathrm{NHS} \\
30 \mathrm{~min}\end{array}$ & $\begin{array}{c}\text { ABR } \\
\text { MAI-411 }\end{array}$ & $\begin{array}{c}\text { Monoclonal } \\
\text { mouse IgG }\end{array}$ & $\begin{array}{c}1: 100 \\
\text { RT } 60 \mathrm{~min}\end{array}$ & $\begin{array}{l}\text { Horse anti- } \\
\text { mouse } \text { IgG }^{1}\end{array}$ & $\begin{array}{c}\text { RT } 45 \text { min } \\
1: 200\end{array}$ & $\begin{array}{l}1.5 \% \text { NHS } \\
\text { in PBS }\end{array}$ & $\begin{array}{l}\text { Mouse } \\
\text { IgG }\end{array}$ \\
\hline $\mathrm{AR}$ & $\begin{array}{c}2 \% \mathrm{NHS} \\
30 \mathrm{~min}\end{array}$ & $\begin{array}{c}\text { DACO } \\
\text { Cytomation } \\
\text { M3562 }\end{array}$ & $\begin{array}{c}\text { Monoclonal } \\
\text { mouse IgG }\end{array}$ & $\begin{array}{c}1: 100 \\
4^{\circ} \mathrm{C} \mathrm{ON}\end{array}$ & $\begin{array}{l}\text { Horse anti- } \\
\text { mouse } \operatorname{IgG}^{1}\end{array}$ & $\begin{array}{c}\text { RT } 30 \mathrm{~min} \\
1: 200\end{array}$ & $\begin{array}{c}2 \% \text { NHS } \\
\text { in PBS }\end{array}$ & $\begin{array}{c}\text { Mouse } \\
\operatorname{IgG}\end{array}$ \\
\hline PGRMC1 & $\begin{array}{l}1.5 \% \mathrm{NHS} \\
30 \mathrm{~min}\end{array}$ & $\begin{array}{c}\text { Sigma } \\
\text { HPA002877 }\end{array}$ & $\begin{array}{l}\text { Polyclonal } \\
\text { rabbit IgG }\end{array}$ & $\begin{array}{l}1: 1000 \\
4^{\circ} \mathrm{C} \mathrm{ON}\end{array}$ & $\begin{array}{c}\text { Horse anti- } \\
\text { mouse/rabbit } \text { IgG }^{2}\end{array}$ & $\begin{array}{c}\text { RT } 30 \mathrm{~min} \\
1: 200\end{array}$ & $\begin{array}{l}1.5 \% \text { NHS } \\
\text { in PBS }\end{array}$ & $\begin{array}{c}\text { Rabbit } \\
\text { IgG }\end{array}$ \\
\hline PGRMC2 & $\begin{array}{l}1.5 \% \mathrm{NHS} \\
30 \mathrm{~min}\end{array}$ & $\begin{array}{c}\text { Sigma } \\
\text { WH0010424M4 }\end{array}$ & $\begin{array}{c}\text { Monoclonal } \\
\text { mouse IgG }\end{array}$ & $\begin{array}{c}1: 2000 \\
4^{\circ} \mathrm{C} \mathrm{ON}\end{array}$ & $\begin{array}{l}\text { Horse anti- } \\
\text { mouse } \mathrm{IgG}^{1}\end{array}$ & $\begin{array}{c}\text { RT } 30 \text { min } \\
1: 200\end{array}$ & $\begin{array}{l}1.5 \% \text { NHS } \\
\text { in PBS }\end{array}$ & $\begin{array}{c}\text { Mouse } \\
\text { IgG }\end{array}$ \\
\hline
\end{tabular}

RT: Room temperature; ON: overnight; NHS: normal horse serum. ${ }^{1}$ Vector Laboratories Cat.no. BA-2000; ${ }^{2}$ Vector Laboratories Cat.no. BA-1400.

Tissue Mini kit (Qiagen GmbH, Hilden, Germany) according to a procedure recommended by the manufacturer for RNA isolation from fatty tissues, as presented elsewhere (25).

Real-time PCR analysis. Real-time PCR was performed in an iCycler $^{\mathrm{TM}}$ iQ Real Time PCR System (Bio-Rad Laboratories, Inc, Hercules, CA USA). For PCR, the cDNAs corresponding to 50-100 ng RNA (see Table I) were added to $12.5 \mu \mathrm{l}$ of $\mathrm{iQ}^{\mathrm{TM}} \mathrm{SYBR}$ Green Supermix (Bio-Rad) and $0.3 \mu \mathrm{M}$ of each oligonucleotide primer in a final volume of $25 \mu$.

After initial incubation for $3 \mathrm{~min}$ at $95^{\circ} \mathrm{C}$, the samples were subjected to 40 cycles of $10 \mathrm{~s}$ at $95^{\circ} \mathrm{C}$, followed by $45 \mathrm{~s}$ annealing at 56 to $62^{\circ} \mathrm{C}$ depending upon the gene (see Table I). All reactions were performed in duplicates. The purity of PCR products was confirmed by a melting-curve analysis in all experiments (data not shown). The oligonucleotide primers for $P R A B, P R B, P G R M C 1$, $P G R M C 2, A R$ and ribosomal phosphoprotein P0 (RPLPO; housekeeping gene) are presented in Table $\mathrm{I}$, as well as the predicted sizes of the products. All primers, except those for $P R B$, were designed to span an intron/exon boundary or to flank an intron, to eliminate amplification of contaminating DNA. The primers are based on the sequences of the human genes (see Accession No. in Table I) and the primer pairs were designed or checked using the NCBI/Primer-BLAST program NCBI, Bethesda, MD, USA. Each PCR assay included a negative control containing a RNA sample without reverse transcriptase. It is not possible to design primers that will detect only $P R A$ mRNA, since the mRNAs for $P R A$ and $P R B$ are transcribed from the same gene and $P R B$ mRNA is longer than $P R A$ mRNA. Therefore, the primer pair for $P R B$ mRNA detects a part of the $P R B$ mRNA that is unique and not translated into PRA, while the PRAB primers will detect both $P R A$ and $P R B$ mRNAs since they are directed to the common sequence of the mRNAs. To obtain an estimate of the PRA mRNA expression, we calculated the ratio of the PCR result for PRAB mRNA and $P R B$ mRNA for every single sample, and used that for statistical evaluation.

To standardize the quantification method, $R P L P O$ was selected out of several tested housekeeping genes as an invariable internal control. The PCR amplification rate and the cycle threshold $(\mathrm{Ct})$ values were related to a standard curve using iCycler iQ Optical System Software (Bio-Rad). The values of relative expression of the genes of interest were normalized against the $R P L P O$ product.

Immunohistochemistry. The tissue sections were deparaffinized using xylene, rehydrated in graded ethanol and subjected to microwave treatment for antigen retrieval in $0.01 \mathrm{M}$ sodium citrate buffer ( $\mathrm{pH} \mathrm{6.0)} \mathrm{for} 10 \mathrm{~min}$ and then allowed to cool for a further $20 \mathrm{~min}$ at room temperature. The assay was performed as previously described elsewhere (25).

The primary antibodies used are presented in Table II. Negative controls were prepared by replacing the primary antibody with mouse IgG (AR, PRA, PRB and PGRMC2) or rabbit IgG (PGRMC1). All dilutions, buffers and incubation times for the different antibodies are shown in Table II. After incubation for 30 (AR, PRA, PGRMC1, PGRMC2) or 60 (PRB) min with horseradish peroxidase-avidin biotin complex (Vectastain Elite, Vector, CA, USA), the bound enzyme was visualized by the application of 3,3'-diaminobenzidine (DAKO Cytomation, Carpinteria, CA, USA). The sections were counterstained with hematoxylin and dehydrated before mounting with Pertex ${ }^{\circledR}$ (Histolab ${ }^{\circledR}$, Askim, Sweden).

Image analysis. To assess the immunostaining quantitatively, a Leica microscope was connected to a computer using Colorvision software (Leica Imaging system Ltd. Cambridge, UK). In a systematic way, 10 fields were randomly selected from the glandular tissue for quantification of the area of positively immunostained (brown) nuclei. The stromal tissue was actively excluded from the measurements. In a few samples when it was not possible to obtain 10 separate sites due to lack of tissue, all glandular tissue was measured. Using color discrimination software, the total area of positively stained nuclei was measured and expressed as a ratio of the total area of cell nuclei (brown reaction product + blue hematoxylin). This method was used for PRA, PRB and AR.

Manual scoring. PGRMC1 and PGRMC2 immunostaining was assessed by manual scoring due to their mainly cytoplasmic staining. The scoring was performed by two independent observers 
on a four-point scale from negative $(-)$, faint $(+)$, moderate $(++)$ and strong (+++) immunostaining. Comparing the results with this method shows good consistency between investigators (28).

Statistical analysis. Statistical analysis was performed by ANOVA on ranks (Kruskal-Wallis test) and significances were evaluated by Dunn's test, either all compared to all, or each compared to a control. Paired analyses were run by Wilcoxon's signed-rank test. Correlations were evaluated by Spearman's test. Values were considered significantly different when $p<0.05$.

\section{Results}

The serum progesterone level was positively correlated to the glandular PRB $(\mathrm{r}=0.551 ; p<0.0017 ; \mathrm{n}=30)$ in normal tissues. Serum levels of IGF-I and SHBG were negatively correlating with glandular $(\mathrm{r}=-0.640 ; p=0.0427 ; \mathrm{n}=10)$ respectively stromal $(-0.873 ; p=0.0000002 ; \mathrm{n}=8)$ PGRMC2 immunostaining in malignant tumors. No correlation to NPI was found in the malignant tumors.

The PRA mRNA level, as assessed as the ratio on an individual level, of PRAB mRNA (Figure 1a, top panel, left column) and PRB mRNA (Figure 1a, bottom panel, left column), was lower in the malignant tumors as compared to that in the normal and benign tissues $(p=0.026 ; n=71)$ (Figure 1a, middle panel, left column). A similar result was found when looking at the samples collected in the follicular phase. Thus, the PRA mRNA level in malignant tumor was lower than the level in benign tumor as well as normal tissue $(p=0.043 ; n=45)$ (Figure 1a, middle panel, middle column), but no differences between groups were found in the luteal phase $(p=0.644$; $\mathrm{n}=26$ ) (Figure 1a, middle panel, right column).

In paired analysis, looking at the tumors and their respective normal tissue, $P R A$ mRNA did not significantly differ in the benign tumors ( $p>0.999 ; \mathrm{n}=22$ pairs $)$, but the malignant tumors expressed less than did the normal tissues ( $p=0.039 ; \mathrm{n}=8$ pairs).

The PRA protein expression (Figure 2a-c) was higher in the glandular epithelium (GE) of benign tumors as compared to those of normal tissue $(p=0.005 ; \mathrm{n}=83$ ) (Figure $1 \mathrm{~b}$, top panel, left column). When considering only at the follicular phase, both benign and malignant tumor tissues showed more immunostaining as compared to the normal tissue $(p=0.009 ; \mathrm{n}=53)$ (Figure 1b, top panel, middle column). In the luteal phase, malignant tissue presented less PRA immunostaining than did benign tumor $(p=0.007 ; \mathrm{n}=29)$ (Figure 1b, top panel, right column).

In paired analyses, more PRA immunostaining was found in the benign tumors $(36 \%)$ than in their respective normal tissues $(15 \%)(p<0.001 ; \mathrm{n}=23)$, a result also valid when considering those in the follicular (35\% and 13\%, respectively; $p<0.001$; $\mathrm{n}=16)$ and luteal ( $37 \%$ and $22 \%$, respectively; $p=0.008 ; \mathrm{n}=7$ ) phases separately. No differences were found for the malignant tumors as compared to their respective normal tissues.
The $P R B$ mRNA level was higher in tumor tissues compared to normal tissues $(p<0.001 ; \mathrm{n}=71)$ (Figure $1 \mathrm{a}$, lower panel, left column), with a similar result when considering only tissues collected in the follicular phase $(p<0.001 ; \mathrm{n}=45)$ (Figure 1a, lower panel, middle column). No difference was found in the luteal phase $(n=26)$ (Figure 1a, lower panel, right column). When considering paired samples, there was higher $P R B$ mRNA expression in the benign tumors as compared to normal tissue $(p<0.001$; $\mathrm{n}=23$ ), but there was no difference for the malignant tumors $(p=0.435 ; \mathrm{n}=11)$.

PRB protein (Figure 2d-f) immunostaining in GE did not differ between the three groups $(p=0.117 ; \mathrm{n}=83$ ), but when considering only the samples collected during the follicular phase, both malignant (61\%) and benign (23\%) tumors showed higher immunostaining than normal tissues (14\%) $(p=0.002 ; \mathrm{n}=54)$ (Figure $1 \mathrm{~b}$, bottom panel, middle column), whereas malignant tumors collected in the luteal phase (3\%) were less immunostained compared to benign tumors (29\%) and normal tissue $(28 \%)$ samples $(p=0.011 ; \mathrm{n}=30)$ (Figure $1 \mathrm{~b}$, bottom panel, right column).

Considering only normal tissue, there was more PRB immunostaining in the luteal phase as compared to the follicular $(p=0.012 ; \mathrm{n}=36)$. In benign tumors, no difference depending on cycle phase was found, but in malignant tumors, PRB immunostaining in the follicular phase was much higher than that in the luteal phase ( $p=0.008 ; \mathrm{n}=13)$.

In paired samples, benign tumors (29\%) showed more PRB immunostaining than the respective normal tissue (19\%) $(p=0.006 ; \mathrm{n}=24)$. When subdividing into menstrual phases, benign tumors $(30 \%)$ were more immunostained than their normal tissue $(14 \%)$ in the follicular phase $(p=0.021 ; \mathrm{n}=14)$, but not in the luteal. The malignant tissue $(54 \%)$ was more immunostained than normal tissue $(14 \%)$ in the follicular phase $(p=0.031 ; \mathrm{n}=6)$, whereas there was a tendency for lower immunostaining in malignant tissue $(2 \% v s .38 \%$ in normal tissue) during the luteal phase $(p=0.063 ; \mathrm{n}=5)$.

The PRGMC1 mRNA level was higher in malignant tumor as compared to normal breast tissue when considering all samples together $(p=0.003 ; \mathrm{n}=71)$ (Figure 3, top panel, left column). When subdividing into follicular and luteal phases and evaluating them separately, only the follicular phase gave the same result, with higher PRGMCl mRNA expression in malignant tumors as compared to normal tissue $(p=0.004 ; \mathrm{n}=45)$. There were no differences between groups in the luteal phase $(p=0.187 ; \mathrm{n}=26)$. In paired analysis, the malignant tissue expressed more PGRMCl mRNA than normal tissues from the same patient ( $00.008 ; n=8)$, but no difference between benign and the respective normal tissue $(p=0.098 ; \mathrm{n}=22)$ was found.

PRGMC1 protein (Figure 2g-i) immunostaining in GE was higher in malignant tumor as compared to benign tissue when analyzing all three groups $(p=0.004 ; \mathrm{n}=85)$ (Figure 3, 

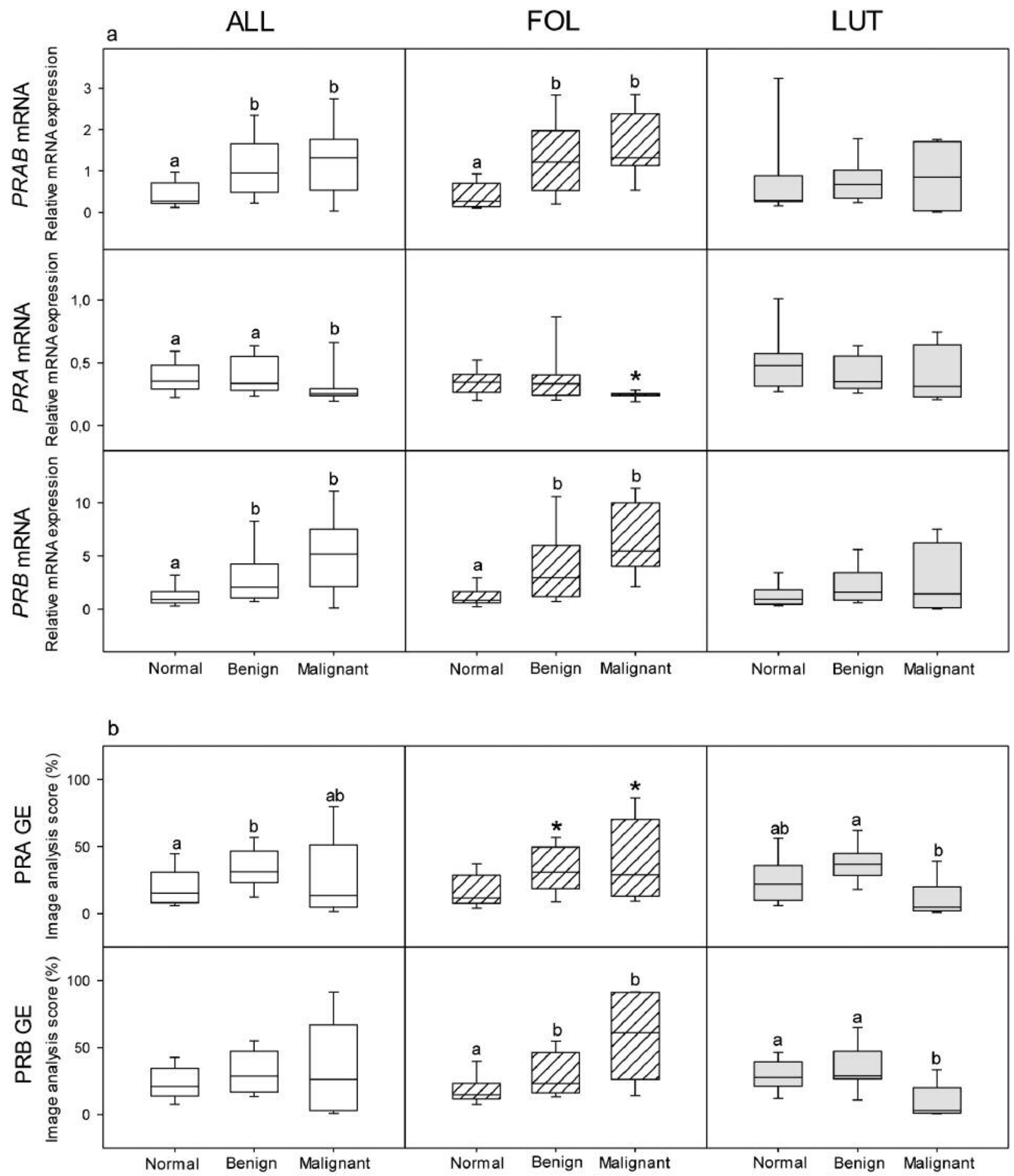

Figure 1. a: The mRNA results, as assessed by real-time polymerase chain reaction using whole-issue homogenates, of progesterone receptor $A B$ (PRAB) (top panel), progesterone receptor A (PRA) (ratio of AB/B; middle panel) and progesterone receptor $B$ (PRB) (bottom panel) are presented. $b$ : The results of PRA (top panel) and PRB (bottom panel) immunostaining in glandular epithelium $(G E)$ as assessed by image analyses are shown. In the left column, the results of all women are presented, in the middle column only those where the samples were collected during the follicular phase (FOL) and in the right column the results from women who were in the luteal phase (LUT) at surgery. The groups comprised seemingly of normal tissue adjacent to tumors (Normal), and the benign (Benign) and malignant (Malignant) tumors; the number of samples were 30 , 30 and 11 , respectively. The box-plots show the median with 50\% of the data falling within the box. The whiskers extend to the 5th and 95 th percentiles. Boxes with different letter designations are significantly different at $p<0.05$. Asterisks demonstrate a significant difference compared to the normal tissue sample. 
top panel, middle column). In stroma, there was a significant difference indicating less immunostaining in malignant tumors as compared to normal tissue $(p=0.030)$ (Figure 3, top panel, right column), but the post hoc test did not define which groups differed.

There was a tendency for higher PGRMC2 mRNA expression in malignant tumors as compared to benign and normal tissues $(p=0.060 ; \mathrm{n}=71$ ) (Figure 3 , bottom panel, left column), a tendency that was also seen when studying only the follicular phase $(p=0.052 ; \mathrm{n}=45)$. In paired analyses, the PGRMC2 mRNA level was higher in malignant tumors as compared to the normal tissues $(p=0.016 ; \mathrm{n}=8)$.

PRGMC2 protein (Figure $2 \mathrm{j}-1$ ) immunostaining in GE was higher in malignant tumor as compared to benign tissue when analyzing all three groups $(p=0.018 ; n=79)$ (Figure 3 , bottom panel, middle column), with a similar tendency when looking only at the follicular phase $(p=0.053 ; \mathrm{n}=51)$. In stroma, benign tumor showed less immunostaining as compared to normal tissue $(p=0.016 ; \mathrm{n}=70)$ (Figure 3 , bottom panel, right column). In paired analysis, stromal PGRMC2 immunostaining was lower in benign tumors than in their respective normal tissues $(p=0.01 ; \mathrm{n}=19)$.

The $A R$ mRNA level was higher in tumor tissues as compared to normal breast tissue when considering all samples together $(p<0.001 ; \mathrm{n}=70)$ (Figure 4 , top panel, left column). When subdividing into follicular and luteal phases, we found the same result, with higher $A R$ mRNA expression in tumor samples as compared to normal tissue $(p<0.001$; $\mathrm{n}=44$ ) (Figure 4, top panel, middle column). There were no differences between groups in the luteal phase $(p=0.576$; $\mathrm{n}=26$ ) (Figure 4 , top panel, right column). In paired analysis of all tumors as compared to their matched normal tissue, the tumors had a higher $A R$ mRNA level than the normal tissue ( $p=0.006 ; \mathrm{n}=29$ pairs). When subdividing the mRNA analyses into follicular $(n=18)$ and luteal $(n=11)$ phases, the AR mRNA level in the follicular phase was higher in the tumors as compared to normal tissue $(p<0.001)$, but there was no difference in samples collected in the luteal phase.

$A R$ protein (Figure $2 \mathrm{~m}-\mathrm{o}$ ) expression was higher in GE of malignant tumors as compared to benign and normal tissues $(p<0.001 ; \mathrm{n}=81)$ (Figure 4, bottom panel, left column). After subdividing into cycle phases, the samples collected from women in the follicular phase showed more AR immunostaining in both benign and malignant tumor tissues as compared to normal tissue $(p<0.001 ; n=52)$ (Figure 4 , bottom panel, middle column). A tendency towards an increased level in malignant tumors as compared to benign and normal tissues was found in the samples collected during the luteal phase $(p=0.061 ; n=29)$ (Figure 4 , bottom panel, right column). In paired analysis of normal versus benign tissues from the same patient, AR protein in GE was more expressed in benign tumors $(46 \%)$ as compared to normal tissues $(29 \%)(p=0.012 ; \mathrm{n}=23)$. In paired analysis of the malignant tumors, there was more AR protein expressed in the tumor $(77 \%)$ as compared to the normal tissue $(36 \%)$ $(p=0.049 ; \mathrm{n}=10)$.

Correlations for the results of the present study are shown in Table III, and correlations between our present results and those from our previous studies are shown in Table IV.

\section{Discussion}

This study was carried out with the specific intention of comparing breast tumors, benign and malignant, with normal breast tissue from the same breast. In this manner we aimed to counter some of the inherent differences between the women, thereby each woman acted as her own control. Although the number of women in this study was small, we found significant differences between the samples which might further our understanding of different hormones acting on breast tissue, and the importance of studying premenopausal women with respect to their menstrual phase.

A previous study states that the protein levels of PRA and PRB, as assessed by western blot, are higher in fibroadenomas compared to normal breast tissues, while the mRNA levels are similar in both tissues (29). These results are in agreement with our paired results from GE of the benign tumors, where the PRA protein level was higher. The PRB protein level was higher when examining the follicular phase. For the whole group and for the luteal phase, there was no difference. We found that there was also a higher $P R B$ mRNA level in benign tumors than in their adjacent normal tissues, whereas Branchini et al. found no differences between the mRNA levels (29).

We found the PRA mRNA level to be lower in malignant tumors compared to benign tissues, both for all samples and in the follicular phase. The PRB mRNA level was increased in malignant tissue as compared to normal tissue, and not different to that of benign tumors. In earlier studies, normal breast epithelium exhibited PRA and PRB in equal amounts.

Figure 2. Immunohistochemical images from normal (left column), benign (middle column) and malignant (right column) breast biopsies. The tissues were stained for progesterone receptor A (PRA) (A-C), PRB $(D-F)$, progesterone receptor membrane component-1 (PGRMC1) $(G$ I), PGRMC2 $(J-L)$ and androgen receptor $(A R)(M-O)$. The negative controls were as follows: PRB monoclonal antibody, incubated for 60 min, and replaced by a similar concentration of mouse $\operatorname{Ig} G(P$, normal tissue); PGRMC2 monoclonal antibody, incubated overnight, replaced by mouse $\operatorname{Ig} G$ at an equivalent concentration ( $Q$, benign tumor); and PGRMC1 polyclonal antibody, incubated overnight, replaced by an equivalent concentration of rabbit $\operatorname{Ig} G$ ( $R$, malignant tumor). Str: Stroma; arrows indicate glands. All figures are shown at a magnification of $\times 200$. 


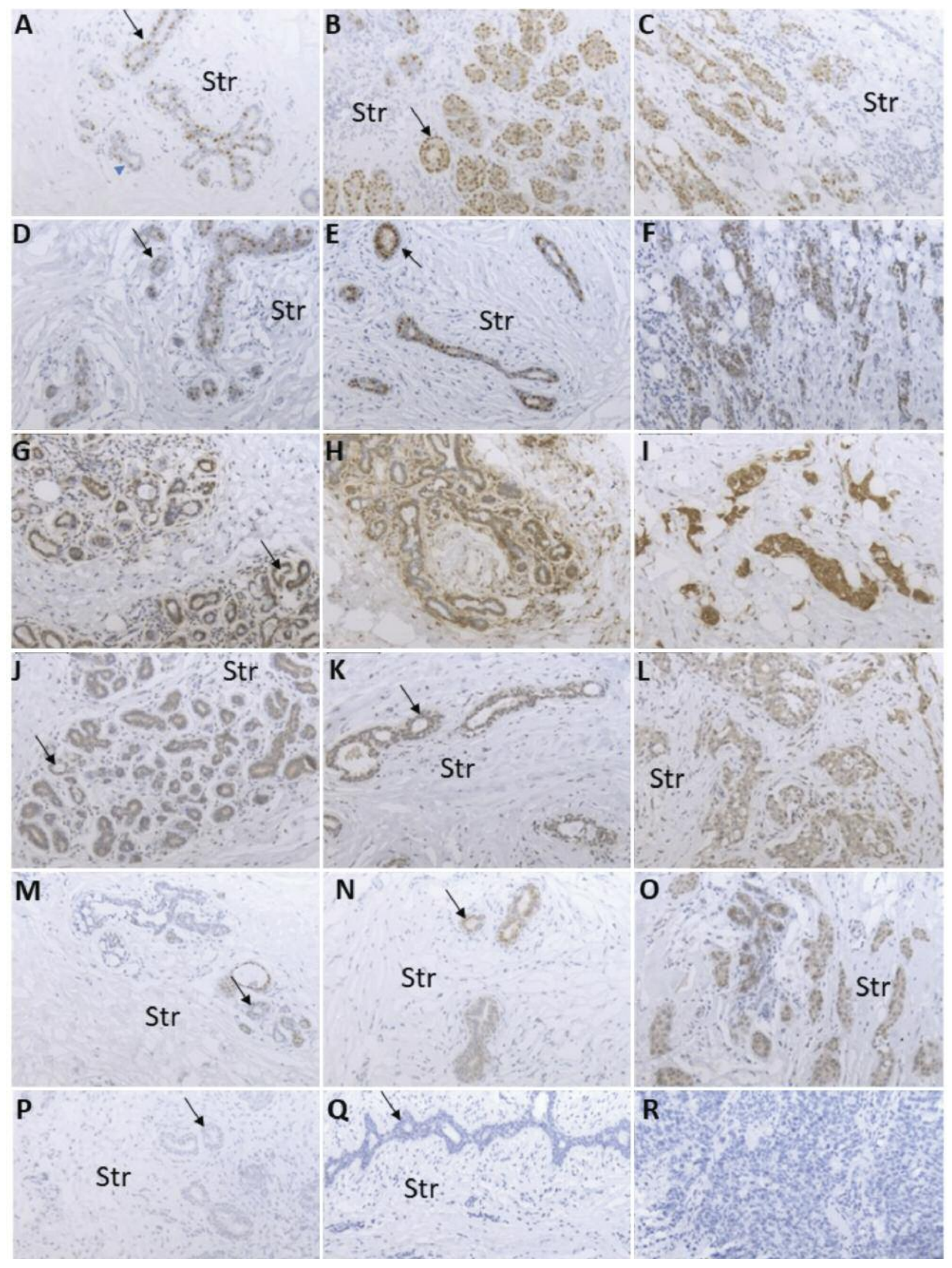



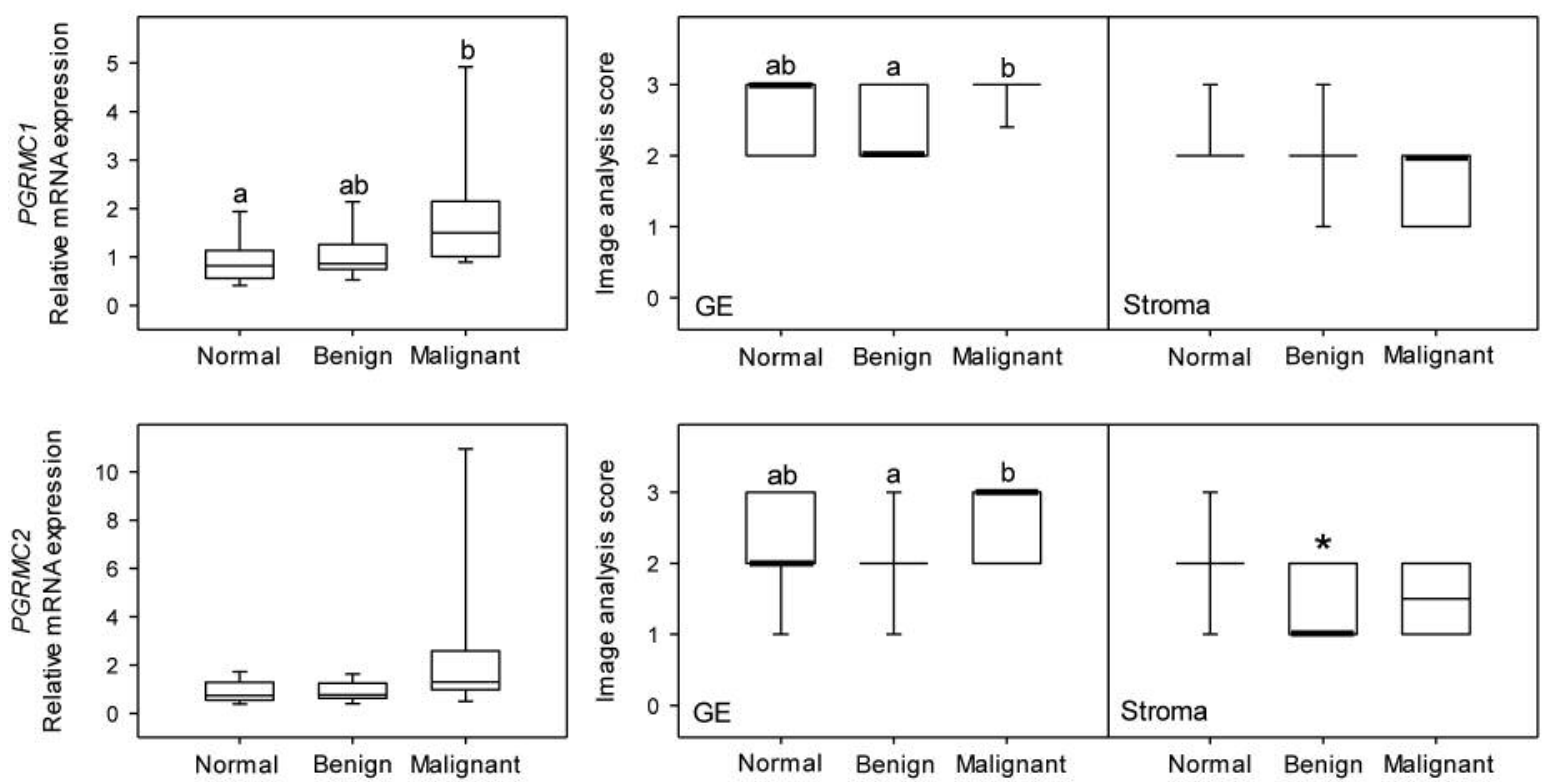

Figure 3. Results as determined by real-time polymerase chain reaction ( $m R N A)$ and assessed by manual scoring of images of progesterone receptor membrane component-1 (PGRMC1) and progesterone receptor membrane component-2 (PGRMC2) immunostaining (protein) are presented. The left column shows the mRNA results, the middle column the immunostaining of the glandular epithelium (GE) and the right column the stromal immunostaining. The top panel shows PGRMC1 (number of samples for mRNA, stroma and GE: Normal tissue=30, 36 and 36; benign tumors=30, 36 and 36; and malignant tumors=11,13 and 13, respectively) and the bottom panel shows PGRMC2 (number of samples for mRNA, stroma and GE: Normal=30, 32 and 29; benign tumors=30, 35 and 31; and malignant tumors=11, 12 and 10, respectively). The box-plots show the median with $50 \%$ of the data falling within the box. The whiskers extend to the 5th and 95th percentiles. Boxes with different letter designations are significantly different at $p<0.05$. Asterisks demonstrate a significant difference compared to the normal tissue sample.

ALL

FOL

LUT

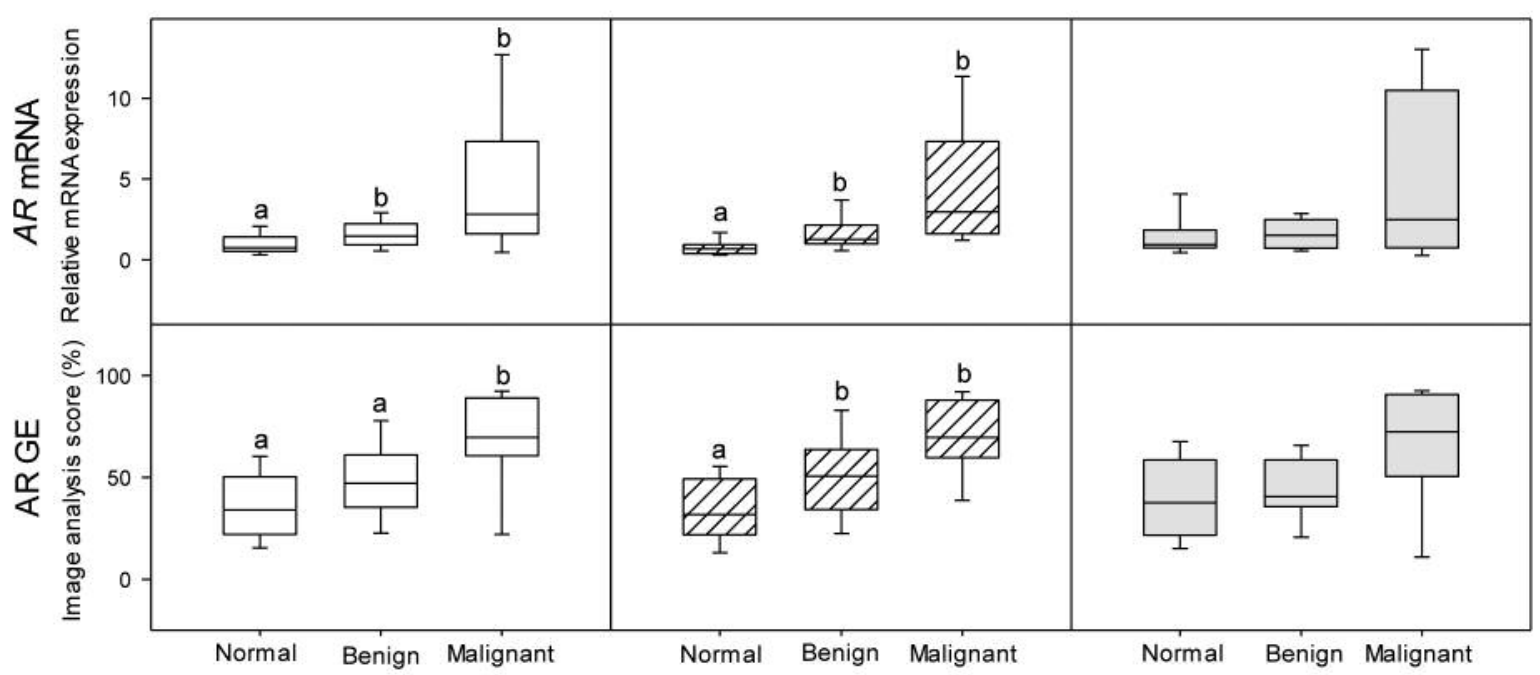

Figure 4. The results of androgen receptor (AR) mRNA determinations (top panel) by real-time polymerase chain reaction in whole tissue homogenate, and immunohistochemical assay of the AR by image analyses in glandular epithelium (GE) (bottom panel). In the left column, the results of all women are presented, in the middle column only those where the samples were collected during the follicular phase (FOL) and in the right column, the results from women who were in the luteal phase (LUT) at surgery; the number of samples were normal tissue=29, benign tumors $=30$, and malignant tumors $=11$. The box-plots show the median with 50\% of the data falling within the box. The whiskers extend to the 5th and 95 th percentiles. Boxes with different letter designations are significantly different at $p<0.05$. 
Table III. Correlation analyses of factors within the present study.

\begin{tabular}{lll}
\hline Factors & $\begin{array}{c}\text { Correlation } \\
\text { coefficient (r) }\end{array}$ & $p$-Value \\
&
\end{tabular}

Normal tissue $(n=30$ unless

otherwise stated)

$P R A B$ mRNA - PRB mRNA

$P R A B$ mRNA - PGRMC1 mRNA

$P R A B$ mRNA - PGRMC2 mRNA

$P R A B$ mRNA - PRA (GE)

$P R B$ mRNA - PRA (GE)

PGRMC1 mRNA - PGRMC2 mRNA

PGRMC1 (GE) - PGRMC2 (GE)

$A R$ mRNA - $P R A B$ mRNA

$A R$ mRNA - $P R B$ mRNA

$A R$ mRNA - PGRMCI mRNA

$A R$ mRNA - PGRMC2 mRNA

$A R$ mRNA - PRA (GE)

AR (GE) - PRA (GE)

$\begin{array}{ll}0.914 & 0.0000002 \\ 0.510 & 0.004 \\ 0.543 & 0.002 \\ 0.655 & 0.0001 \\ 0.637 & 0.0002 \\ 0.880 & 0.0000002 \\ 0.589(\mathrm{n}=27) & 0.0013 \\ 0.744(\mathrm{n}=29) & 0.0000002 \\ 0.636(\mathrm{n}=29) & 0.0002 \\ 0.754(\mathrm{n}=29) & 0.0000002 \\ 0.753(\mathrm{n}=29) & 0.0000002 \\ 0.532(\mathrm{n}=29) & 0.003 \\ 0.537(\mathrm{n}=28) & 0.003\end{array}$

Benign tissue ( $\mathrm{n}=30$ unless

otherwise stated)

$P R A B$ mRNA - PRB mRNA

$P R A B$ mRNA - PRA (GE)

$P R A B$ mRNA - PRB (GE)

PGRMC1 mRNA - PGRMC2 mRNA

PGRMC1 (GE) - PGRMC2 (GE)

PGRMC2 (str) - PGRMC2 (GE)

$A R$ mRNA - PGRMC1 mRNA

$A R$ mRNA - PGRMC2 mRNA

Malignant tissue ( $\mathrm{n}=11$ unless

otherwise stated)

$P R A B$ mRNA - PRB mRNA

PRA (GE) - PRB (GE)

$P G R M C 1$ mRNA - PGRMC2 mRNA

PGRMC1 mRNA - PRA (GE)

PGRMC1 mRNA - PRB (GE)

$A R$ mRNA - PGRMCI mRNA

$A R$ mRNA - PGRMC2 mRNA

AR (GE) - PGRMC2 (str)

$\begin{array}{ll}0.887 & 0.0000002 \\ 0.513(\mathrm{n}=29) & 0.005 \\ 0.604 & 0.0004 \\ 0.734 & 0.0000002 \\ 0.608 & 0.0004 \\ 0.541(\mathrm{n}=27) & 0.004 \\ 0.721 & 0.0000002 \\ 0.678 & 0.00003\end{array}$

Table IV. Correlation analyses of factors in the present study to factors studied in Fahlén et al. (25) and Fahlén et al. (26).

\begin{tabular}{lll}
\hline Factors & $\begin{array}{c}\text { Correlation } \\
\text { coefficient (r) }\end{array}$ & $p$-Value \\
\hline
\end{tabular}

Normal tissues $(\mathrm{n}=30$ unless

otherwise stated)

$E R \alpha$ mRNA - PRAB mRNA

$E R \alpha$ mRNA - PRB mRNA

$E R \alpha$ mRNA - PGRMC1 mRNA

$E R \alpha$ mRNA - PGRMC2 mRNA

$E R \alpha$ mRNA - AR mRNA

ER $\alpha$ mRNA - PRA (GE)

$E R \beta$ mRNA - PGRMCl mRNA

$E R \beta$ mRNA - PGRMC2 mRNA

$E R \beta$ mRNA - AR mRNA

$C T G F$ mRNA - PRAB mRNA

$C T G F$ mRNA - PRB mRNA

PGRMCI mRNA - GPER mRNA

PGRMC1 mRNA - ER $\alpha 36$ mRNA

$P G R M C 2$ mRNA - GPER mRNA

PGRMC2 mRNA - ER 36 mRNA

PGRMC2 mRNA - CTGF mRNA

PGRMC2 - CTGF (GE)

Benign tissue ( $\mathrm{n}=30$ unless

otherwise stated)

ER $\alpha$ mRNA - PGRMCI mRNA

$E R \alpha$ mRNA - AR mRNA

$E R \beta$ mRNA - PGRMC1 mRNA

$E R \beta$ mRNA - PGRMC2 mRNA

GPER (GE) and PGRMC1 (GE)

$\begin{array}{ll}0.747 & 0.0000002 \\ 0.703 & 0.000003 \\ 0.587 & 0.0007 \\ 0.578 & 0.0009 \\ 0.822(\mathrm{n}=29) & 0.0000002 \\ 0.548 & 0.002 \\ 0.616 & 0.0003 \\ 0.728 & 0.0000002 \\ 0.546(\mathrm{n}=29) & 0.002 \\ 0.527 & 0.003 \\ 0.538 & 0.002 \\ 0.652 & 0.00009 \\ 0.628(\mathrm{n}=27) & 0.0005 \\ 0.735 & 0.0000002 \\ 0.693(\mathrm{n}=27) & 0.00004 \\ 0.527 & 0.003 \\ 0.535(\mathrm{n}=27) & 0.004\end{array}$

$\begin{array}{ll}0.527 & 0.003 \\ 0.596 & 0.0005 \\ 0.668 & 0.00004 \\ 0.671 & 0.00004 \\ 0.567 & 0.001\end{array}$

Malignant tissues ( $\mathrm{n}=11$ unless

otherwise stated)

$P R A B$ mRNA - ER $\beta$ (Str)

$P R A B$ MRNA - CTGF (GE)

$P R B$ mRNA - $C T G F$ mRNA.

PRB (GE) and COX-1 (Str)

PGRMC1 mRNA - COX-1 (Str)

$P G R M C 2$ mRNA - ER $\alpha$ mRNA

$P G R M C 2$ mRNA - ER $\beta$ mRNA

$P G R M C 2$ mRNA - CTGF mRNA

$P G R M C 2$ mRNA - ER $\alpha$ (GE)

PGRMC2 mRNA - COX1 (Str)

PGRMC2 (GE) - ER $\alpha$ (GE)

PGRMC2 (GE) - ER $\beta$ mRNA

PGRMC2 (GE) - GPER MRNA

$A R$ mRNA - ER $\alpha$ mRNA

$A R$ mRNA - ER $\beta$ mRNA

$A R$ mRNA - ER 36 mRNA

$A R$ mRNA - CTGF mRNA

$A R$ mRNA - ER $\alpha(\mathrm{GE})$

the cancer tumors retained the $1: 1$ ratio, but a third of the

tumors exhibited a much higher prevalence of PRA (10). In today's clinical setting, the commonly used antibodies for immunohistochemistry do not distinguish between PR isoforms. This is regrettable, as an understanding of the levels of PRA vs. PRB might gain some predictive and prognostic insight (30).

There were some differences when comparing follicular and luteal phases: generally, mRNA and protein levels of PRA, PRB, AR, PGRMC1 and 2 in the tumors, both benign and malignant, as compared to the normal tissue (the paired
COX1: Cyclooxygenase 1; CTGF: connective tissue growth factor; ER: estrogen receptor; PR: progesterone receptor; PGRMC: progesterone receptor membrane component; AR: androgen receptor; GPER: G protein-coupled estrogen receptor. Negative correlations shown in bold.

samples) were higher in the follicular phase. The exception was PRA mRNA, which was lower in malignant tumors when looking at all samples, or those of the follicular phase. 
Ever since 1989, there has been an ongoing debate whether the timing of surgery matters in premenopausal women (31), the theory being that it is more hormonally beneficial to carry out surgery in the luteal phase. However, a Cochrane review from 2011, did not confirm any effects on overall or disease-free survival after surgery in different menstrual phases (32).

The PRA mRNA level was lower in malignant tumors as compared to benign and normal tissue in the follicular phase. PRA protein in the follicular phase however, was more abundant in tumors, both malignant and benign, than in normal tissue. When looking at the luteal phase, there was less PRA protein in the malignant as compared to the benign tumors. $P R B$ mRNA was higher in the tumors than in the normal tissue, both when looking at all samples and those of the follicular phase. PRB protein expression was higher in tumors when looking at the follicular phase only. Thus, the phase when the tumor is surgically removed could influence whether the tumor is $\mathrm{PR}+$ or PR-. Other studies have determined the occurrence of PR in benign and malignant tumors dividing into luteal and follicular phase, but found no significant difference between these menstrual phases $(28,33,34)$.

PGMRC1 is indicated to be a vital part of progestogens acting on breast cells, in particular to mediate an apoptotic effect (35). We found a higher level of PGMRC1, at both the mRNA and protein level, in malignant tissue as compared to benign tissue. This is in accordance with previous studies $(36,37)$. PGMRC1 expression decreases with age (15), hence the relatively higher levels that were found in malignant tissue in our study, really marks a relationship with malignancy, considering these women tended, if anything, to be older (25). A higher level of PGMRC1 appears to sensitize breast cancer cells to proliferation in relation to estradiol (38). However, we found no significant correlations to NPI, perhaps due to the small sample size of malignant tumors.

Lack of AR is considered a poor prognostic marker coupled to a worse prognosis (39). In a recent study, the levels of both AR protein and mRNA were found to be higher in low-grade tumors with better prognosis. The authors concluded that their results are in agreement with previous studies, also showing that AR expression features in cancer with good prognosis, and in correlation with older patient age, small tumor size, lower tumor grade with lower proliferative activity and lower NPI. They also stated that the prognostic value of AR expression varies significantly depending on the ER status (40). In our study, the AR protein and mRNA levels were higher in malignant tumors than in normal tissue, not only when comparing the three groups, but also when comparing the tumors with their own normal control tissues. The finding was valid when looking at all samples, and those in the follicular phase, with a similar trend also found for the luteal phase. We also found a strong correlation between $E R \alpha$ mRNA and $A R$ mRNA in all tissues in our study, but in malignant tissue, there was a positive correlation between $A R$ mRNA and glandular ER $\alpha$ staining, indicating a special relationship in the malignant tumor. We did not find any relationship between AR and NPI. To the best of our knowledge, no comparison between AR mRNA levels in benign, normal and malignant breast tissue has been previously presented.

In the clinical context, it has become clear that in about $30 \%$ of $\mathrm{ER}^{+}$breast cancer cases, tamoxifen has no effect. There are also signs of acquired tamoxifen resistance. The reasons for both de novo and acquired resistance have been sought in connection with ERs, PRs and AR. Therefore, a better knowledge of how to interpret not only PRs, but also other receptors, such as the membrane-bound progesterone receptors PGMRC1 and-2 and AR, becomes important.

\section{Conclusion}

We found that a malignant breast tumor could appear to be PR-negative if collected in the luteal phase, but PR-positive in the follicular phase. This fact may have clinical implications. Thus, progesterone receptors, including isoforms and membrane-bound receptors, constitute an important area in the understanding of normal breast development. A more thorough analysis of these receptors and the AR can be of great help in determining the aggressiveness of an individual breast tumor. It may also shed some light on the occurrence of tamoxifen resistance, making a selection of adjuvant therapy more tailored towards the individual woman.

\section{Acknowledgements}

The Authors are grateful to Professor Lambert Skoog for the pathological re-evaluation of the samples, and to Lavanya Ramimeni for technical assistance. This study was supported by the regional agreement on medical training and clinical research (ALF) between Stockholm County Council and Karolinska Institute (LS; BvS); Cancer Society in Stockholm, CFS (EvS), The Swedish Breast Cancer Association, BRO (MF) and Karolinska Institute. Hua Zhang was a postdoctoral fellow supported by the Chinese Government (grant 2008850544).

\section{References}

1 Yue W, Yager JD, Wang JP, Jupe ER and Santen RJ: Estrogen receptor-dependent and independent mechanisms of breast cancer carcinogenesis. Steroids 78(2): 161-170, 2013.

2 Salmen J, Neugebauer J, Fasching PA, Haeberle L, Huober J, Wockel A, Rauh C, Schuetz F, Weissenbacher T, Kost B, Stickeler E, Klar M, Orlowska-Volk M, Windfuhr-Blum M, Heil J, Rom J, Sohn C, Fehm T, Mohrmann S, Loehberg CR, Hein A, Schulz-Wendtland R, Hartkopf AD, Brucker SY, Wallwiener D, Friese K, Hartmann A, Beckmann MW, Janni W and Rack B: 
Pooled analysis of the prognostic relevance of progesterone receptor status in five German cohort studies. Breast Cancer Res Treat 148(1): 143-151, 2014.

3 Sorlie T, Perou CM, Tibshirani R, Aas T, Geisler S, Johnsen H, Hastie T, Eisen MB, van de Rijn M, Jeffrey SS, Thorsen T, Quist $\mathrm{H}$, Matese JC, Brown PO, Botstein D, Lonning PE and BorresenDale AL: Gene expression patterns of breast carcinomas distinguish tumor subclasses with clinical implications. Proc Natl Acad Sci USA 98(19): 10869-10874, 2001.

4 Bauerschlag DO, Maass N and Schem C: Standard of care and controversies in the adjuvant endocrine treatment of hormoneresponsive early breast cancer. Breast Care 9(4): 283-286, 2014.

5 Sherman MR, Corvol PL and O'Malley BW: Progesteronebinding components of chick oviduct. I. Preliminary characterization of cytoplasmic components. J Biol Chem 245(22): 6085-6096, 1970

6 Brisken C and O'Malley B: Hormone action in the mammary gland. Cold Spring Harb Perspect Biol 2(12): a003178, 2010.

7 Conneely OM, Mulac-Jericevic B, Lydon JP and De Mayo FJ: Reproductive functions of the progesterone receptor isoforms: lessons from knock-out mice. Mol Cell Endocrinol 179(1-2): 97 103, 2001 .

8 Wang S, Counterman LJ and Haslam SZ: Progesterone action in normal mouse mammary gland. Endocrinology 127(5): 21832189,1990

9 Abdel-Hafiz H, Takimoto GS, Tung L and Horwitz KB: The inhibitory function in human progesterone receptor $\mathrm{N}$ termini binds SUMO-1 protein to regulate autoinhibition and transrepression. J Biol Chem 277(37): 33950-33956, 2002.

10 Mote PA, Graham JD and Clarke CL: Progesterone receptor isoforms in normal and malignant breast. Ernst Schering Found Symp Proc (1): 77-107, 2007.

11 Brisken C: Hormonal control of alveolar development and its implications for breast carcinogenesis. J Mammary Gland Biol Neoplasia 7(1): 39-48, 2002.

12 Chlebowski RT, Hendrix SL, Langer RD, Stefanick ML, Gass M, Lane D, Rodabough RJ, Gilligan MA, Cyr MG, Thomson CA, Khandekar J, Petrovitch H, McTiernan A and Investigators WHI: Influence of estrogen plus progestin on breast cancer and mammography in healthy postmenopausal women: the Women's Health Initiative Randomized Trial. JAMA 289(24): 3243-3253, 2003.

13 Kaminska M, Ciszewski T, Lopacka-Szatan K, Miotla P and Staroslawska E: Breast cancer risk factors. Prz Menopauzalny 14(3): 196-202, 2015.

14 Fournier A, Berrino F and Clavel-Chapelon F: Unequal risks for breast cancer associated with different hormone replacement therapies: results from the E3N cohort study. Breast Cancer Res Treat 107(1): 103-111, 2008.

15 Causey MW, Huston LJ, Harold DM, Charaba CJ, Ippolito DL, Hoffer ZS, Brown TA and Stallings JD: Transcriptional analysis of novel hormone receptors PGRMC1 and PGRMC2 as potential biomarkers of breast adenocarcinoma staging. J Surg Res 171(2): 615-622, 2011.

16 Neubauer H, Ruan X, Schneck H, Seeger H, Cahill MA, Liang Y, Mafuvadze B, Hyder SM, Fehm T and Mueck AO: Overexpression of progesterone receptor membrane component 1: possible mechanism for increased breast cancer risk with norethisterone in hormone therapy. Menopause 20(5): 504-510, 2013
17 Wendler A and Wehling M: PGRMC2, a yet uncharacterized protein with potential as tumor suppressor, migration inhibitor and regulator of cytochrome P450 enzyme activity. Steroids 78(6): 555-558, 2013.

18 Lubahn DB, Joseph DR, Sullivan PM, Willard HF, French FS and Wilson EM: Cloning of human androgen receptor complementary DNA and localization to the X chromosome. Science 240(4850): 327-330, 1988.

19 Walters KA, Simanainen U and Gibson DA: Androgen action in female reproductive physiology. Curr Opin Endocrinol Diabetes Obes 23(3): 291-296, 2016.

20 Zhou X: Roles of androgen receptor in male and female reproduction: lessons from global and cell-specific androgen receptor knockout (ARKO) mice. J Androl 31(3): 235-243, 2010.

21 Kennedy BJ: Fluoxymesterone therapy in advanced breast cancer. N Engl J Med 259(14): 673-675, 1958.

22 Haines CR, Wallace HJ Jr., Nevinny HB and Hall TC: Clinical evaluation of estrogen-androgen combination in advanced breast cancer. Am J Surg 117(4): 589-594, 1969.

23 Vera-Badillo FE, Templeton AJ, de Gouveia P, Diaz-Padilla I, Bedard PL, Al-Mubarak M, Seruga B, Tannock IF, Ocana A and Amir E: Androgen receptor expression and outcomes in early breast cancer: a systematic review and meta-analysis. J Natl Cancer Inst 106(1): djt319, 2014.

24 Christopoulos PF, Vlachogiannis NI, Vogkou CT and Koutsilieris M: The role of the androgen receptor signaling in breast malignancies. Anticancer Res 37(12): 6533-6540, 2017.

25 Fahlen M, Zhang H, Lofgren L, Masironi B, E VONS, BO VONS and Sahlin L: Expression of estrogen receptors in relation to hormone levels and the Nottingham Prognostic Index. Anticancer Res 36(6): 2839-2847, 2016.

26 Fahlen M, Zhang H, Lofgren L, Masironi B, von Schoultz E, von Schoultz B and Sahlin L: Expression of cyclooxygenase-1 and cyclooxygenase- 2 , syndecan- 1 and connective tissue growth factor in benign and malignant breast tissue from premenopausal women. Gynecol Endocrinol 33(5): 353-358, 2017.

$27 \mathrm{Wu}$ W, Shi SQ, Huang HJ, Balducci J and Garfield RE: Changes in PGRMC1, a potential progesterone receptor, in human myometrium during pregnancy and labour at term and preterm. Mol Hum Reprod 17(4): 233-242, 2011.

28 Isaksson E, Wang H, Sahlin L, von Schoultz B, Cline JM and von Schoultz E: Effects of long-term HRT and tamoxifen on the expression of progesterone receptors $\mathrm{A}$ and $\mathrm{B}$ in breast tissue from surgically postmenopausal cynomolgus macaques. Breast Cancer Res Treat 79(2): 233-239, 2003.

29 Branchini G, Schneider L, Cericatto R, Capp E and Brum IS: Progesterone receptors $\mathrm{A}$ and $\mathrm{B}$ and estrogen receptor alpha expression in normal breast tissue and fibroadenomas. Endocrine 35(3): 459-466, 2009.

30 Diep CH, Daniel AR, Mauro LJ, Knutson TP and Lange CA: Progesterone action in breast, uterine and ovarian cancers. J Mol Endocrinol 54(2): R31-53, 2015.

31 Hrushesky WJ, Bluming AZ, Gruber SA and Sothern RB: Menstrual influence on surgical cure of breast cancer. Lancet 2(8669): 949-952, 1989.

32 Samuel M, Wai KL, Brennan VK and Yong WS: Timing of breast surgery in premenopausal breast cancer patients. Cochrane Database Syst Rev (5): CD003720, 2011. 
33 Liu Y, Wang Y, Zhou L, Yin K, Yin W and Lu J: Prognostic effect of menstrual cycle on timing of surgery in premenopausal breast cancer patients. Am J Surg 210(3): 506-511, 2015.

34 Pujol P, Daures JP, Brouillet JP, Chang S, Rouanet P, Bringer J, Grenier J and Maudelonde T: A prospective prognostic study of the hormonal milieu at the time of surgery in premenopausal breast carcinoma. Cancer 91(10): 1854-1861, 2001.

35 Peluso JJ, Romak J and Liu X: Progesterone receptor membrane component-1 (PGRMC1) is the mediator of progesterone's antiapoptotic action in spontaneously immortalized granulosa cells as revealed by PGRMC1 small interfering ribonucleic acid treatment and functional analysis of PGRMC1 mutations. Endocrinology 149(2): 534-543, 2008.

36 Stanczyk FZ: Can the increase in breast cancer observed in the estrogen plus progestin arm of the Women's Health Initiative trial be explained by progesterone receptor membrane component 1? Menopause 18(8): 833-834, 2011.

37 Zhang Y, Ruan X, Willibald M, Seeger H, Fehm T, Neubauer H and Mueck AO: May progesterone receptor membrane component 1 (PGRMC1) predict the risk of breast cancer? Gynecol Endocrinol 32(1): 58-60, 2016.
38 Neubauer H, Yang Y, Seeger H, Fehm T, Cahill MA, Tong X, Ruan $\mathrm{X}$ and Mueck AO: The presence of a membrane-bound progesterone receptor sensitizes the estradiol-induced effect on the proliferation of human breast cancer cells. Menopause 18(8): 845-850, 2011.

39 Ricciardi GR, Adamo B, Ieni A, Licata L, Cardia R, Ferraro G, Franchina T, Tuccari G and Adamo V: Androgen Receptor (AR), E-Cadherin and Ki-67 as Emerging targets and novel prognostic markers in triple-negative breast cancer (TNBC) patients. PLoS One 10(6): e0128368, 2015.

40 Aleskandarany MA, Abduljabbar R, Ashankyty I, Elmouna A, Jerjees D, Ali S, Buluwela L, Diez-Rodriguez M, Caldas C, Green AR, Ellis IO and Rakha EA: Prognostic significance of androgen receptor expression in invasive breast cancer: transcriptomic and protein expression analysis. Breast Cancer Res Treat 159(2): 215-227, 2016.

Received November 25, 2017

Revised January 15, 2018

Accepted January 29, 2018 